\title{
Patrick O'Brien on industrialization, little Britain and the wider world
}

\author{
Peer Vries* \\ International Institute of Social History, Amsterdam, North-Holland, Netherlands \\ *Corresponding author. E-mail: peer.vries@iisg.nl
}

\begin{abstract}
Patrick O'Brien has dedicated most of his career to studying British economic history, focusing on the Industrial Revolution, its antecedents, characteristics and consequences. He has always paid attention to long-term developments and never confined himself to strictly economic aspects. From the late 1990s onward, he increasingly turned 'global'. His importance for global history cannot be overstated. His essay in this issue presents the outcome of his long intellectual journey. I will in this rejoinder try to assess his approach and his findings and comment on Patrick as a scholar and as a person. As we are close friends I will be critical.
\end{abstract}

Keywords: British; Industrial; Global; Economic history; Industrial revolution

\section{Against the wind}

In my experience trying to determine what a person rejects, is always an effective strategy to find out what he or she is up to. Patrick is clearly against specific Whig interpretations of British economic history which maintain that industrialization occurred first in Britain because it had a distinctive set of institutions, first and foremost its 'representative' state and its market economy. Such views have long been influential through the work of Douglass North, Robert Thomas and Barry Weingast, who emphasized the importance of secure and well-described property rights that they claimed were established with the Glorious Revolution of $1688 .{ }^{1}$ It has recently been restated in an adapted form by Daron Acemoğlu and James Robinson, who focus on the assumed inclusiveness of Britain's political and economic institutions. ${ }^{2}$ Patrick's work has extensively and effectively demolished such theses. In numerous studies, including this essay, he has focused on what he calls 'less benign' aspects of the British polity. Britain's state politically was not exactly inclusive. He prefers to describe it as aristocratic, autocratic, confessional or fiscal-military, to just give a few of his not very flattering characterizations. Coercion, control, expropriation, and redistribution in favour of the wealthy and powerful played a much larger role in British history than is suggested by scholars who focus on property rights, representation and inclusiveness. Economically it was quite un-egalitarian, with a system of public finance that benefitted the wealthy while burdening the ordinary population with high taxes.

Domestically there was substantial intervention in the economy, particularly in relation to labour and land markets. Internationally, trade, economy, state, war and empire were inseparably

\footnotetext{
${ }^{1}$ Douglass North and Robert Thomas, The rise of the Western world. A New Economic History (Cambridge, 1973); Douglass North and Barry Weingast, 'Constitutions and Commitment: The Evolution of Institutions Governing Public Choice in Seventeenth-Century England,' The Journal of Economic History 49, 4 (1989): 803-32.

${ }^{2}$ Daron Acemoglu and James Robinson, Why Nations Fail. The Origins of Power, Prosperity and Poverty (London, 2012). 
connected. ${ }^{3}$ That connection has been a recurring topic in Patrick's work. Some sixty years ago he presented a thesis on Britain's fiscal and financial policy in the wars against France in 1793-1815; currently he is editing a volume on the economic outcomes of the Revolutionary and Napoleonic Wars for a number of European states. He suggests that those wars may have actually been beneficial for Britain's economy. He is convinced there was no realistic laissez-faire alternative for Britain's mercantilist policies. ${ }^{4}$ Their effects on the growth of Britain's economy in his view, overall, were positive. His forceful plea to connect 'power and plenty' has certainly helped put this connection back on the agenda of many (economic) historians. ${ }^{5}$

Patrick has also persistently opposed - and continues to oppose in this essay - explanations of Britain's industrialization referring to an exceptional British culture. Well-known proponents of this claim would be David Landes, Jack Goldstone, Deirdre McCloskey and Joel Mokyr. ${ }^{6}$ He sees nothing particularly 'enlightened', 'progressive', 'bourgeois' or 'virtuous' in the country's elites. Indeed, they were for him far from enlightened in the way they ruled the country and in their thinking about liberté, egalité, and fraternité. Nor does he think Britain's businessmen and investors were exceptionally entrepreneurial. His overall judgement may be harsh - to which I return below - but who can blame someone with Irish roots for not being overly enthusiastic about British, or rather English, culture?

Such criticisms by Patrick do not mean that he denies any value to analysing culture for economic history. From 2009 to 2013 he led a major research project on regimes for the production, development and diffusion of useful and reliable knowledge in the East and the West from the accession of the Ming to the Opium War, a project clearly inspired by the likes of Max Weber and Joseph Needham. This compelled him to delve deeply into literature on cosmologies and religions, a testament to his wide-ranging interests and capability to digest huge amounts of information. ${ }^{7}$

Another idea about the Industrial Revolution in Britain that Patrick clearly rejects is turning it into a paradigm for developing countries to follow. In his view there is no model for industrialization, not even in the nineteenth century. ${ }^{8}$ It would thus be a mistake to transform Britain's industrialization into 'a paradigm case for liberal and neo-liberal models of economic development.' All the more so because, according to him, it was just an 'unexceptional discontinuity in the history of a well-endowed island economy.' To my taste at least, Patrick's characterization of the industrialization of Britain as 'unexceptional' or 'unremarkable' is debateable. These are not terms that I would use to describe the first instance of modern economic growth which initiated a huge and lasting transformation in the global economy. The same goes for his description of the

\footnotetext{
${ }^{3}$ Patrick O'Brien, 'Inseparable connexions: Trade, economy, fiscal state and the expansion of empire, 1688-1815,' in The Oxford History of the British Empire, eds. P.J Marshall, Vol. 2, The Eighteenth Century (Oxford, 1998), 53-77.

${ }^{4}$ See the Conclusion of Patrick O’Brien, 'The contributions of warfare with Revolutionary and Napoleonic France to the consolidation and progress of the British Industrial Revolution,' LSE Department of Economic History Working Paper, 150, 2011.

${ }^{5}$ See e.g. Ronald Findlay and Kevin O'Rourke, Power and Plenty. Trade, War, and the World Economy in the Second Millennium (Princeton, 2007) and Sven Beckert, Empire of Cotton. A Global History (New York, 2014).

${ }^{6}$ David Landes, The Wealth and Poverty of Nations. Why Some are So Rich and Some So Poor (New York and London, 1998); Jack Goldstone, 'Efflorescences and economic growth in world history: Rethinking the "Rise of the West" and the Industrial Revolution,' Journal of World History 13, no. 2 (2002): 323-89; Deirdre McCloskey, The Bourgeois Virtue. Ethics for an Age of Commerce (Chicago, 2006); idem, Bourgeois Dignity. Why Economics Can't Explain the Modern World (Chicago, 2010); idem, Bourgeois Equality. How Ideas, not Capital or Institutions Enriched the World (Chicago, 2016); Joel Mokyr, The Enlightened Economy. An Economic History of Britain 1700-1850 (New Haven and London, 2009); idem, A Culture of Growth. The Origins of the Modern Economy (Princeton and Oxford, 2017).

${ }^{7}$ Patrick O'Brien, 'Historical Foundations for a Global Perspective on the Emergence of a Western European Regime for the Discovery, Development and Diffusion of Useful and Reliable Knowledge,' Journal of Global History 8, no. 1 (2013): 1-24; idem, 'Useful and Reliable Knowledge in Europe and China,' in Global Economic History, eds. Giorgio Riello and Tirthankar Roy (London, 2019), 54-66.

${ }^{8}$ Patrick O’Brien, 'Do We Have a Typology for the Study of European Economic History in the XIXth Century?,' Journal of European Economic History 15, no. 2 (1986): 291-333.
} 
revolution as 'predictable'. I wonder whether 'novelty' ever is. In any case it is telling that no one saw it coming, not even Adam Smith.

Many other characterizations in his text show that he wishes to qualify the actual impact of the Industrial Revolution in Britain. The impact of that revolution's famous new technologies was, in his view, long confined to particular sectors of the economy and from our current perspective the growth rates of GDP were not exactly impressive. Both these comments seem correct to me. But a critic might want to point out that innovations always take time to spread and that when its industrialization began Britain was in many respects already the most advanced economy in the world. The initial impact of technological innovations on macro-economic growth in such economies is as a rule rather small. Just consider the impact of the computer on the GDP of advanced Western economies. Moreover, in the case of the British Industrial Revolution it should be pointed out that total output growth in manufacturing, where the famous technological innovations originated, was much higher than in agriculture and somewhat higher than in services. ${ }^{9}$

In defence of Britain's Industrial Revolution being revolutionary, one can also point to three other facts. First, the population of England, Wales and Scotland roughly trebled between 1760 and 1860. Second, the period of British industrialization included the years of total war against France from the 1790s till 1815, at the height of which between $11 \%$ and $14 \%$ of the country's adult male population was under arms. Third, a succession of bad harvests - in, e.g., 1795-96, 1799, 1808-12 and 1816-17 - occurred over this period. Personally, I would not describe an economy experiencing real growth per capita in such a situation at that time, and which continued to do so afterwards while at the same time extending its empire, as merely passing through an 'unexceptional discontinuity'. This was something novel. That Britain's global economic primacy was temporary need not come as a surprise. What is surprising is that such a small island with so few inhabitants could at all be an economic and political global superpower for decades, at its height ruling over one fourth of the globe's population and surface. The revolutionary and global importance of the First Industrial Revolution for me is that it opened a fundamentally new trajectory in global economic history. What would the world have looked like without steam in factories and on trains and ships?

\section{A matter of definition?}

Britain's Industrial Revolution apparently carries more significance for the history of the world for me than it does for Patrick. That may well be because our definitions and chronologies are not identical. If we identify the Industrial Revolution with the first instance of modern economic growth, i.e. sustained and substantial growth of real GDP per capita, what should we conclude on the basis of the figures of Broadberry and his co-authors which suggest that this growth was, albeit with major differences between sectors, only $0.45 \%$ p.a. in $1780-1800,0.20 \%$ p.a. in $1800-30$ and $1.26 \%$ p.a. in $1830-70$ ? Does this amount to something new and substantial? ${ }^{10}$ If the Industrial Revolution is identified with the transition to a mineral-based, fossil-fuel energy economy, as I would following Tony Wrigley and Jack Goldstone, then the entire period from 1760 to at least 1830 looks still pre-industrial and its growth still mainly pre-modern. ${ }^{11}$ Major changes in the use of energy (in the form of massive use of steam power in industry and transport) and in technology, and in the character and rate of growth only occurred in the 1830s - or even later. This would mean that industrialization was a post-1830 phenomenon. If, as Patrick does, the Industrial Revolution is identified, referring to Kuznets, with a process of primarily economic structural change, then one may question whether what happened in Britain in the period usually

\footnotetext{
${ }^{9}$ Broadberry and others, British Economic Growth, 208.

${ }^{10}$ Broadberry and others, British Economic Growth, 204.

${ }^{11}$ E.A. Wrigley, Continuity, Chance \& Change. The Character of the Industrial Revolution in England (Cambridge, 1989) chapter 3 and Goldstone, 'Efflorescences and Economic Growth'.
} 
associated with its Industrial Revolution actually conforms to Kuznets' model. The percentage of the labour force (male and female labour combined) working in agriculture was already below $50 \%$ in 1710, whereas the percentage of the labour force (again male and female labour combined) working in manufacturing hardly changed at all between 1710 and 1871 . That is hard to reconcile with the shifts in sectoral employment which for Kuznets define industrialization. ${ }^{12}$ If the phenomenon is identified à la David Landes with the rise of the factory system (encompassing the substitution of machines for human skill and effort, the replacement of animate by inanimate sources of power and the use of new and more abundant raw materials), this will probably lead to yet another periodization and assessment. ${ }^{13}$ Patrick's definition seems to mix elements from the definitions of Kuznets, Wrigley and Landes, and is not very explicit when it comes to chronology, in particular concerning the supposed 'end' of the Revolution: 1830, 1846 or 1873? In contrast, I prefer the Wrigley-Goldstone interpretation and the periodization it implies, and base my assessment of the revolution's global importance thereupon.

Patrick's apparent reticence to give a very exact definition and a very precise chronological demarcation has methodological disadvantages. But it is a logical outcome, and as such justifiable, of his conviction that the Industrial Revolution was not a short, sharp discontinuity - founded upon, say, a couple of fundamental technological breakthroughs - but a complex phenomenon which, as shown by the causes he adduces, had been centuries in the making, and in fact never stopped. This is a position which I basically endorse, even though it precludes a strict causal explanation: a complex, not fully-determined 'co-incidence' of different developments all associated with 'industrialization' is not a variable. It is worth noting, however, that Patrick's interpretation fundamentally differs from that of many global economic historians, especially members of the so-called California School, who emphasise that the Industrial Revolution was a rapid and unexpected outcome of a combination of specific circumstances which only emerged sometime late in the eighteenth century and who write about it in terms of 'discontinuity' and 'rupture'. ${ }^{14}$ That combination of circumstances is usually presented as 'fortuitous' or 'contingent'. ${ }^{15}$ In this respect too Patrick seems to disagree as he calls the Industrial Revolution 'rather predictable.'

\section{A global perspective}

It will come as no surprise that Patrick makes a plea to look at the global dimensions and antecedents of the industrialization of Britain and other Western countries. When most economic historians nowadays consider that as rather obvious, this to a large extent is thanks to his efforts to create a global economic history, which, as Tirthankar Roy and Giorgio Riello recently claimed, would not exist as a field without him. ${ }^{16}$ Intellectually and practically, Patrick was the driving force behind the Global Economic History Network and all of its activities. He set up a master's programme in global history at the LSE. He was the founder of Journal of Global History, whose first issue was launched with a prologue by him of almost forty pages about the traditions of writing

\footnotetext{
${ }^{12}$ Leigh Shaw-Taylor and A.E. Wrigley, 'Occupational Structure and Population Change,' in The Cambridge Economic History of Modern Britain, eds. Roderick Floud, Jane Humphries and Paul Johnson, Volume I, 1700-1870 (Cambridge, 2014), 54 and 69. According to Broadberry and his co-authors the sectoral share in nominal GDP of industry was about as high in 1841 as it had been in 1759, whereas that of the service sector increased substantially. See their British Economic Growth, 195.

${ }^{13}$ Landes, Wealth and Poverty, 186.

${ }^{14}$ See e.g. Jack Goldstone, Why Europe? The Rise of the West in World History, 1500-1800 (New York, 2008) VIII; Peter Perdue, China Marches West. The Qing Conquest of Central Eurasia (Cambridge Mass./London, 2005) 537; Kenneth Pomeranz, The Great Divergence. China, Europe, and the Making of the Modern World Economy (Princeton, 2000$), 7$ and 9.

${ }^{15}$ For examples see Peer Vries, Escaping Poverty, The Origins of Modern Economic Growth (Göttingen and Vienna, 2013 ), 50-1.

${ }^{16}$ See the dedication in their Global Economic History.
} 
global history. ${ }^{17}$ The effort he has put into 'his mission' has been staggering. His efficiency and effectiveness are amazing. His 'global turn' is in a sense a return to the beginning of his career when he wrote about the history of Egypt and the USA. As a comparativist, he long focused on the economic development of Britain and France. ${ }^{18}$ More recently his comparisons have become truly global. ${ }^{19}$ Ironically, when it comes to global connections, what is probably his most famous article ends with the conclusion that the 'world economy' hardly impinged on the economic development of pre-industrial Western Europe and that the contribution of the periphery to its growth was peripheral. ${ }^{20}$ Patrick no longer believes in that thesis as his thinking has shifted away from analysing simple balance sheets of commodity exchange. ${ }^{21}$

\section{A two-stage explanation}

Directly or indirectly the British Industrial Revolution has always been at the heart of Patrick's research. The essay under review contains the results of a long quest for its causes. He comes up with a two-stage explanation by first showing how, in Wrigley's terms, Britain became an exceptionally advanced organic economy, and then discussing the technological changes that formed the core of the actual revolution. ${ }^{22}$

The first factor singled out is Britain's agriculture. He points to its high labour productivity, resulting in a low percentage of total labour force working in it and enabling a rapid rate of urbanization. He also points to the prominent role of livestock husbandry and of animals, mainly horses, as sources of energy. I can only endorse Patrick's position and add some extra figures and comments. Between 1700 and 1850 the share of livestock outputs as a percentage of total agricultural outputs hovered between $38 \%$ and $55 \% .{ }^{23}$ Apparently the country was never in serious Malthusian trouble. Holding livestock was, and is, is a very inefficient way of producing food in terms of calories as compared to growing crops and on average it required roughly half of all agricultural land in Britain over those 150 years. The number of sheep, swine, milk and beef cattle, calves and horses all roughly doubled between 1750 and $1850 .{ }^{24}$ Britain could have reserved much more land for simply feeding itself. Instead, the country allowed itself to focus on the more lucrative livestock farming and on importing food in exchange for manufactured products. The number of working horses illustrate the importance of animals as an energy source. In English agriculture alone, their number was at least 700,000 in 1815 and about 800,000 in $1850 .{ }^{25}$ On top of that, there was about an equal number of non-farm horses. Over a year one mature horse could do as much physical work as six to eight adult males. Britain's agriculture was very peculiar. The contrast with, for

\footnotetext{
${ }^{17}$ Patrick O’Brien, 'Historiographical Traditions and Modern Imperatives for the Restoration of Global History,' Journal of Global History 1, no. 1 (2006): 3-40.

${ }^{18}$ See e.g. Patrick O’Brien and Caglar Keyder, Economic Growth in France and Britain, 1789-1914. Two Paths to the Twentieth Century (London, 1978); Patrick O’Brien, 'Path Dependency, or Why Britain Became an Industrialised and Urbanised Economy Long Before France,' Economic History Review, New Series 49, no. 2 (1996): 213-49.

${ }^{19}$ See e.g. Bartolomé Yun-Casalilla and Patrick O’Brien with Francisco Comín Comín, eds., The rise of fiscal states. A global history (Cambridge 2012); Patrick O'Brien, The economies of Imperial China and Western Europe. Debating the Great Divergence (Cham, Switzerland 2020).

${ }^{20}$ Patrick O’Brien, 'European Economic Development. The Contribution of the Periphery', Economic History Review 35, no. 1 (1982): 1-18.

${ }^{21}$ For balance sheets see Patrick O’Brien, 'The Costs and Benefits of British Imperialism, 1846-1914,' Past \& Present 120 (1988): 163-200; Patrick O'Brien and Leandro Prados de la Escosura, 'Balance Sheets for the Acquisition, Retention and Loss of European Empires Overseas,' Itinerario 23(3-4) (1999): 25-52.

${ }^{22}$ For that concept see Wrigley, Continuity, Chance \& Change.

${ }^{23}$ Stephen Broadberry and others, British Economic Growth, 1270-1870 (Cambridge, 2015): 118.

${ }^{24}$ Broadberry, British Economic Growth, 106-13. The estimate given for mature working horses on page 111 strikes me as quite high. Compare the following note.

${ }^{25}$ Astrid Kander and Paul Warde, 'Energy Availability from Livestock and Agricultural Productivity in Europe, 1815-1913: A New Comparison,' Economic History Review 64, no. 1 (2010): 24.
} 
example, China's rice agriculture at the time could hardly be greater. Britain's use of coal too was exceptional in relation to Europe and the wider world. Already by 1700 almost half of its total energy consumption was provided by fossil fuels, incomparably higher than anywhere else. ${ }^{26}$

Patrick's ideas regarding Britain's state in the early modern era and the nineteenth century and its importance for Britain's trade should by now be sufficiently familiar to not need further explanation. He has expounded them in numerous articles and does so again in the essay under discussion. The only thing I want to point out here is the extent to which these publications too show British exceptionalism. According to Patrick, the post-Restoration state became 'outstandingly successful' in raising funds. Thanks to its 'exceptional' system of collecting taxes and servicing national debt, it was able to sustain 'remarkably high' levels of military expenditure and build 'the world's largest navy'. This helped in acquiring an 'inordinate share' of the gains from international commerce. Having created 'exceptional levels' of external security, Britain's state could also deal with internal stability, law and order, and support the national economy, institution-building and the provision of public goods.

Providing arguments to substantiate the claim that Britain's state and its policies contributed to economic growth and that there was no alternative to being 'mercantilist' is easy. But this does not mean Patrick's reasoning is water-tight. One may for example ponder the implications of the fact that, calculated over the entire period from 1700 to the end of the Napoleonic Wars, military expenditure and exports amounted to roughly $10 \%$ of GDP each. Given that the value added of exports is by definition lower than their total value, this means that Britain spent more on the military than it earned in exports. The assumption, moreover, that it spent more on the military than necessary for sheer defence is not unreasonable. While Patrick asks the question whether Britain's rulers were over-spending on their military, he does not really answer it. A unilateral withdrawal from the prevailing geopolitical world was indeed not a realistic option. But was there no other alternative to building the military apparatus and the empire that were actually built? Parliament never refused funds for war. Selling bonds was never a problem. Mercantilists did not complain. Britain's elites were apparently happy with the existing system which means in practice there was no alternative. But does this mean it was good for GDP?

One could also question the emphasis on the role of the state in Patrick's reasoning from another angle. It figures so prominently because it facilitated, protected and supported trade. The focus of course is on exports. These provided income. Between 1784 and 1856 roughly two-thirds of exports went to Europe, the United States and Latin America, regions over which the British did not rule. How exactly did Britain's state matter for those exports? I assume that people there bought British products - almost exclusively manufactured goods - voluntarily and because they provided value for money. Does this not suggest that developments in manufacturing 'caused' trade rather than the other way around? Historical causality is of course not as straightforward as suggested in the previous sentence. But I nevertheless think Patrick's reference to 'securing commerce overseas' as a causal factor in industrialization - rather than in the growth of the service sector - is not unproblematic from a methodological point of view. Besides, the domestic markets of Qing China were much larger than the sum of all the markets the British had to secure for themselves at huge cost. Patrick's focus on the importance of exports for the manufacturing sector is understandable. But one may nevertheless wonder what it means for his explanation of industrialization and growth that exports in total only amounted to some $10 \%$ of GDP.

This brings us to the direct cause of most changes in production, namely, technology. While Patrick fully acknowledges the importance of technological inventions and innovations, he spends many sentences contextualising and qualifying them. They are understood against longer-term developments without which they could not have occurred. They often consisted of 'borrowings' or 'adaptations' from knowledge and techniques from elsewhere. They were often a matter of further developing, improving and diffusing rather than actual novelty. Their initial impact should

\footnotetext{
${ }^{26}$ Warde, Energy Consumption, 69.
} 
not be overestimated nor should their complexity. All very true. But these qualifications cannot do away with the fact that the exceptional and in the longer run very consequential wave of innovations which we associate with the Industrial Revolution occurred in Britain between the middle of the eighteenth and nineteenth centuries, and not somewhere else and not at some other time. ${ }^{27}$ In my view, these innovations were not an 'inevitable' outcome of all the contextualization that Patrick provides - which to be fair he does not suggest. There remains a substantial 'residual' of things unexplained in his explanation of the major innovations. The presence of this residual provides even more of a challenge as Patrick does not seem to embrace Robert Allen's line of reasoning and rejects that of Joel Mokyr (in my view too harshly). ${ }^{28}$ When we focus on those people who were actively involved in changing Britain's mode of producing and their networks, and not on the ruling elite, it is hard to sustain the argument that taken as a collective they were 'unexceptional'. The hypothesis that Britain at the time was indeed distinctive in certain aspects of its 'culture' or 'system' of innovation and its human capital has not been refuted. This hypothesis still yields new insights and can be readily tested without assuming some British 'geniality'. ${ }^{29}$ The good scholar that he is, Patrick does not exclude the possibility of such research bearing fruit.

One final comment is in order with regard to Patrick's reasoning. Britain's industrialization has always been at the heart of the debate on the Great Divergence between, in particular, Britain and China. Reading Patrick's essay, one is bound to conclude that in several fundamental respects Britain was already quite exceptional, and very different from China, long before it industrialized. This provides a clear refutation of Pomeranz's widely acclaimed 'surprising-resemblances thesis', which I have always considered odd. ${ }^{30}$ Apart from the fact that they both were pre-industrial before the Industrial Revolution, Qing China and early modern Britain were about as different as preindustrial economies, and societies, could be. ${ }^{31}$ It is yet another sign of Patrick's open-mindedness and magnanimity that he always refers in highly positive terms to Kenneth Pomeranz and the other Californians - including to their surprising resemblances thesis - for bringing into play new perspectives, new questions and new claims. Real scholarship proceeds on an open battlefield via conjectures and refutations, and not in trenches sheltering behind dogmas.

\section{The litmus-test question}

I have never come across a historian who denied that industrialization, however defined, was a watershed in global history. That being the case, assessing the place of Britain's Industrial Revolution in global history boils down in the end to determining whether there would have been industrialization in its absence. How likely is it that something similar in characteristics and impact would have occurred anyhow, somewhere sometime soon? Patrick suggests that developed modern economies would have been just as productive without the Industrial Revolution in Britain when he claims: 'Very few economic historians ... claim that the current levels of labour productivity achieved by the world's market economies today would look different but for the economic transformation wrought by Britain between 1763 and 1846.' My hunch - of course unprovable - is that it is not very likely, given how different Britain apparently was from elsewhere, that another country would have

\footnotetext{
${ }^{27}$ For that wave see Leonard Dudley, Mothers of Innovation. How Expanding Social Networks Gave Birth to the Industrial Revolution (Newcastle upon Tyne, 2012) 61, 82 and 110. The lists on those pages show that somehow Britain must have been 'different'.

${ }^{28}$ Patrick O’Brien, 'A Conjuncture in Global History or An Anglo-American Construct: The British Industrial Revolution, 1700-1850,' Journal of Global History 5, no. 3 (2010): 503-9. A review of Robert Allen, The British Industrial Revolution in Global Perspective (Cambridge, 2009) and Mokyr, Enlightened Economy.

${ }^{29}$ See for innovation Dudley, Mothers of innovation and for human capital formation Morgan Kelly, Joel Mokyr and Cormac O'Grada, 'The Mechanics of the Industrial Revolution', June 2020 CEPR Discussion Paper No DP14884.

${ }^{30}$ Pomeranz, Great Divergence, Part One, 'A World of Surprising Resemblances'.

${ }^{31}$ See for many such differences Peer Vries and Annelieke Vries, Atlas of Material Life. Northwestern Europe and East Asia, Fifteenth to Nineteenth Century (Leiden, 2020).
} 
become the first to experience an industrial revolution any time soon. I fail to see a country that could and would have been able to step in quickly for Britain with a similar effect. Even if it was not his intent, Patrick shows convincingly that Britain was quite exceptional. I assume that ceteris paribus the more exceptional something is the harder it is to find a substitute for it. Though catching up - at least for a couple of Western countries and later on Japan - was 'relatively' easy, this does not prove that it was straightforward to be the first. So, on what grounds could another country - be it France, the Netherlands or the USA, seen as the most obvious candidates - be reasonably expected to have industrialized first instead of Britain?

\section{Three in one}

The ideal professor nowadays is supposed to be an excellent researcher, an inspiring teacher, and a successful academic entrepreneur. It is hard enough being one of these. Patrick has excelled in all three roles. He covers a very broad range of subjects without becoming superficial or losing sight of 'the big questions'. According to Noam Chomsky intellectuals - or rather a specific kind of them, the establishment intellectuals - are specialists in defamation, essentially political commissars and ideological administrators who feel most threatened by dissidence. In that sense, Patrick is the opposite of an intellectual. He is not smug but interested in other people and their ideas, willing to question his own points of view and even change them. On top of all that, he is a very nice person. It is great fun to disagree with him. We have debated a lot over the years. It would have made him very suspicious and uncomfortable if I had merely praised him in this rejoinder. I hope to have many more opportunities to disagree with him in future. 